\title{
Erratum to: Effect of hydraulic retention time on the performance of down-flow hanging sponge system treating grey wastewater
}

\author{
Ahmed Tawfik - Rifaat Abdel Wahab • \\ Azza Al-Asmer • Fatma Matary
}

Published online: 26 June 2011

(c) Springer-Verlag 2011

\section{Erratum to: Bioprocess Biosyst Eng}

DOI 10.1007/s00449-011-0528-9

Erratum to the conclusion section

Accordingly, it is recommended to operate such a system at an HRT not exceeding $5.8 \mathrm{~h}$ and OLR of $3.6 \mathrm{~kg} \mathrm{COD/}$ $\mathrm{m}^{3}$ day for producing an effluent quality complying for reuse in unrestricted irrigation purposes [39].

39. Tawfik A, Abdel Wahaab R, Al-Asmer A, Matary F (2011) Optimization of down-flow hanging sponge (DHS) system treating grey wastewater for reuse in irrigation purposes. Int J Sustain Water Environ Syst 3(1):13-18

The online version of the original article can be found under doi:10.1007/s00449-011-0528-9.

A. Tawfik $(\square)$

School of Energy Resources and Environmental Engineering, Egypt-Japan University of Science and Technology (E-Just), P.O. Box 179, New Borg El Arab City, Alexandria 21934, Egypt e-mail: Tawfik8@hotmail.com; ahmed.tawfik@ejust.edu.eg

A. Tawfik · R. A. Wahab Water Pollution Research Department, National Research Center, El-Behouth St., Dokki, P.O. Box 12622, Cairo, Egypt

\section{A. Al-Asmer - F. Matary}

Demitta Branch, Faculty of Science, Department of Environmental Science, Mansoura University, Mansoura, Egypt 